\title{
ФІЛАС ВІКТОР,
}

кандидат історичних наук, доцент кафедри дизайну, Хортищька національна академія, м. Запоріжжя

\section{МАНІПУЛЯЦІЯ ВІЗУАЛЬНИМИ ОБРАЗАМИ В ІДЕОЛОГІЧНИХ КОНЦЕПЦІЯХ, АБО ЯК "ВІДБІЛЮВАЛИ" ІМІДЖ Г. ПОТЬОМКІНА}

\begin{abstract}
У статті зазначається, що тиражна графіка, починаючи 3 кінця XVIII ст., активно використовувалась у конструюванні суспільної думки шляхом корегування образів. На основі аналізу творів живопису та гравюр, присвячених облозі Очакова 1788 р., простежено процес конструювання позитивного образу Г. О. Потьомкіна на тлі його непопулярних заходів щодо взяття фортеці. Зокрема, зазначається, що після штурму Очакова з'явилися створені на замовлення картини олією Ф. Казанови "Штурм Очакова" та серії гравюр І. Вілля, де створено позитивний образ Г. Потьомкіна. Також фріксується "уведення" фігури князя в сюжет гравюри, створеної А. Баршем за аквареллю очевидця штурму фортеці художника М. Іванова. Зазначається, що твори живопису та графіки повинні були подолати негативний образ Г. Потьомкіна щодо подій під Очаковом. Після смерті Катерини II образ Г. Потьомкіна переходить у негативну площину, на тлі цього роздмухується позитивний військовий геній О. Суворова.
\end{abstract}

Ключові слова: Північне Причорномор'я; російсько-турецькі війни; гравюра; ідеологія; образ; конструювання.

Постановка проблеми та стан її дослідження. Інформативні можливості візуальних джерел 3 історії Північного Причорномор'я дозволяють визначити місце регіону в ідеологічних концепціях російських монархів, а також простежити їі особливості та трансформацію.

3 приводу відображення державних ідеологічних концептів існує ряд наукових розвідок переважно літературоцентричного напрямку. Серед цих робіт значне місце посідають роботи А. Зоріна [2001] та В. Проскуріної [2006]. У них доволі детально розглянуто відносини в трикутнику "влада - ідеологія - література" у другій половині XVIII - середині XIX ст. Питання живопису та графіки з одного боку і влади та ідеології з іншого знаходиться на маргінесі наукових досліджень. Загальнотеоретичні роботи, де порушувалися питання взаємодії ідеології та візуального мистецтва, аналізують в основному події XX ст. Серед цих робіт знаковими $є$ розвідки літературознавця та історика мистецтв Т. Мітчела [2002], соціолога та історика В. Боннелл [2007], психолога Г. Орлової [2009] та інших. Разом із тим, прийоми формування суспільної думки за допомогою візуальних інструментів впливу відомі були набагато раніше, а їх більш ретельне дослідження в контексті більш ранніх історичних подій та пов'язаних із ними історичних персон дозволить говорити про них як про ідеальні засоби поширення бажаних (заданих) форм соціальної взаємодії.

Мета статті - на основі аналізу творів живопису та гравюр, присвячених облозі Очакова 1788 р., простежити процес конструювання позитивного образу Г. О. Потьомкіна.

Виклад основного матеріалу. Ідеологія $€$ одним із головних фракторів, які впливають на художню культуру в цілому. Вона прямо або опосередковано впливає на ії зміст, шляхи та принципи розвитку у творчості худож- ників, скульпторів, літераторів тощо. Ідеологія проявляється зазвичай у складних опосередкованих та завуальованих формах. У творах живопису та графріки вона проявляється через обрану художником тематику, ідейну позицію побудови сюжету, інтерпретацію творів живопису та графіки, де формується система естетичних оцінок для публічного засвоєння.

Маючи потужні важелі, держава впливала на тематику, формування ідеї сюжету та потрібну їй інтерпретацію, упроваджуючи в масову свідомість певну сукупність ідей. Розкриття того, який комплекс ідей утілювався, за допомогою яких механізмів, а також місця регіону Північного Причорномор'я останньої чверті XVIII ст. в цьому процесі становить певний науковий та практичний інтерес.

Центральною міфрологемою катерининських часів був так званий "Грецький проект", який Катерина II крок за кроком упроваджувала в життя. Він не був реалізований до кінця, тобто не було відтворено Візантійську імперію на чолі з її онуком Костянтином. Але навіть проміжні його результати - приєднання до імперії земель Північного Причорномор'я - внесли значні корективи у світовий геополітичний пасьянс. Саме успішність процесу втілення "Грецького проекту" постійно підтверджувала легітимність перебування на престолі Катерини II як гаранта непорушності дворянської імперії.

Міцність влади та їі легітимність потребували постійного ідеологічного підживлення. Влада постійно шукала нові канали та теми для якісного нарощування та укріплення державної ідеології. Одним із безпрограшних варіантів цього процесу була ідеалізація військової історії. Найбільш успішним вектором зовнішньої політики Катерини II був південний вектор. Дві російськотурецькі війни 1768-1774 рр. та 1787-1791 рр. зробили 
значний внесок в укріплення влади Катерини II. Звісно, що ці ключові події стали центральними складниками ідеологічної парадигми російської дворянської імперії. Поряд із літературою, театром, музикою, архітектурою, скульптурою до процесу ідеологічного закріплення успіхів катерининського правління долучились і живопис та графріка.

Центральне місце в російсько-турецькому протистоянні займало Північне Причорномор'я. Інформаційний потенціал візуальних джерел з історії Північного Причорномор'я дає нам можливість висвітлити окремі аспекти питання конструювання ідеологічних схем російським урядом. Північнопричорноморську серію малюнків цього періоду умовно можна розподілити на три групи. До першої та другої групи належать архітектурні пейзажі та етнографічні замальовки, що були своєрідними "репортажами", які задовольняли інтерес громадськості до нового, приєднаного до Росії регіону. Третім складником візуальних трансляцій із регіону було висвітлення військових подій з акцентом на російськотурецьку війну 1787-1791рр. Державне замовлення на візуалізацію реальності Північного Причорномор'я шляхом створення робіт живопису та графіки мало військово-ідеологічне спрямування. Стратегія російських еліт у відборі до тиражування малюнків та акварелей була направлена на корегування фріксування події з метою впровадження того конструкту, який треба було пам'ятати підданим.

Візуальні джерела з історії Північного Причорномор'я дають нам змогу говорити про політику утвердження Г. Потьомкіна як ключової фрігури при просуванні Російської імперії на Південь у ході реалізації ідеологічного концепту "Грецького проекту". По це говорять особливості продукування та фрормування сюжетів візуальних джерел, що висвітлюють події російсько-турецьких війн останньої чверті XVIII ст., у результаті яких Росія анексувала північне узбережжя Чорного та Азовського морів.

Фігура Г. Потьомкіна є ключовою у військово-ідеологічних гравюрах С. Шифляра, І. Вілля та А. Барша. Центральним епізодом у гравюрі австрійського майстpa І. Вілля "Фельдмаршал Г. А. Потьомкін приймає полоненого турецького пашу" є процес капітуляції турецького гарнізону. Комендант фортеці Очаків Гасан-Паша стоїть перед Г. Потьомкіним, який сидить на бочці на тлі свого оточення. Заднім планом сюжету служить зображення штурму фортеці Очаків. Наявність різночасових елементів у сюжеті - капітуляції фортеці (передній план) та процесу штурму (задній план) свідчить про конструювання цього сюжету на замовлення. Характерною рисою гравюри є умовність у зображенні всіх ії̈ елементів. Ключову роль у трактовці сюжету відіграє назва гравюри, або артіонім, а не точність та достовірність зображення. Образ Г. Потьомкіна промальований умовно. Автор намагався не передати подію, а зафіксувати їі фракт та разом з інформацією артіоніма підкреслити ключову роль Г. Потьомкіна в усій очаківській компанії 1788 р. Подібною є й інша робота І. Вілля "Облога Очакова". Центром сюжету цієї гравюри є Г. Потьомкін, який, як і Петро I, на здибленому коні разом із військами йде на штурм Очакова. Тут, як і в попередньому випадку, очаківська фортеця має умовний, дещо європеїзований характер.

Гравюра роботи А. Барша теж зображує штурм очаківських мурів. Про достовірність сюжету можна судити 3 того, що автором малюнка до гравюри був М. Іванов рисувальник при штабі Г. Потьомкіна, який був очевид- цем подій і створив цілу серію малюнків на тему "очаківського сидіння". Центром переднього плану сюжету $€$ особа, у якій вгадуються загальні риси обличчя Г. Потьомкіна, що веде російські війська на очаківські мури. 3 документів відомо, що Г. Потьомкін не брав участі у таких "гарячих" фразах штурму. Як головнокомандувач він знаходився у тилу при штабі й звідти керував штурмом. Найшвидше, його фрігура була вставлена в реальне зображення штурму штучно, що гравер і зробив. На оригіналі М. Іванова, що зберігається в Російському музеї в Санкт-Петербурзі, ця фігура має трохи іншу позу та вигляд обличчя.

Окрім тиражної графіки очаківські події 1788 р. знайшли своє відображення й у живописі. Одразу після російсько-турецької війни в 1791 р. російський уряд замовив Ф. Казанові дві картини на тему взяття Очакова та Ізмаїла. Ці замовлення створювались художником у Відні на основі карт, схем, малюнків та спогадів. Головним сюжетом "Штурму Очакова" знов виступає фігура Г. Потьомкіна. Він стоїть у центрі в освітленому навколо нього тлі в оточенні офріцерів. Поряд із князем - турецький офіцер. Судячи із сюжету, тут зображено процес капітуляції турецького гарнізону. Але тут же з іншого краю $€$ хлопчик та кінь. Із приводу цього канцелярист та перекладач, учасник очаківської компанії Р. Цебриков пише, що "чув від хлопчика-поляка з Очакова, який прийняв магометанську віру, що християни, які залишились в Очакові, вкинуті в ямах сажнів на 10 ... Цей хлопчик привів із собою коня, за якого ясновельможний заплатив йому 200 рублів, який за оцінкою інших не більше 80 рублів коштує" [Цебриков, 1895: 169]. Тобто факт спілкування хлопчика та князя зафіксовано також і в мемуарних джерелах. Очевидно, Ф. Казанова, формуючи сюжет, поєднав дві різночасові події: процес капітуляції як прояв "військового генія" Г. Потьомкіна та купівлю за великі гроші коня в дитини як благородство та великодушність.

Як бачимо, військова сюжетна іконографія Г. Потьомкіна має свою особливість. Вона локалізована винятково навколо очаківської облоги. Очаківська кампанія була однією з ключових подій російсько-турецької війни 1787-1791рр. Дії Г. Потьомкіна під Очаковом мали несхвальні відгуки сучасників. Його критикували за нерішучість i, як наслідок, за недосконалий військовий досвід та посередні навички. Сама очаківська кампанія тривала з кінця весни до початку грудня. О. Суворов декілька разів пропонував розпочати штурм фортеці, використавши слушні моменти під час турецьких вилазок. Подібної думки дотримувався й австрійський головнокомандувач Ш.-Ж. де Лінь та П. Румянцев [Осипов, 1949]. Саме критика дій Г. Потьомкіна під час облоги Очакова відомими полководцями стала запорукою того, що його досить сильно критикували як сучасники, так і історики. У дореволюційній історіографії дії Г. Потьомкіна під час облоги Очакова не схвалювались [Брикнер, 1891; Петров, 1880]. Радянська ж історіограффія ставила за приклад позитивний бойовий запал О. Суворова [Бескровный (ред.), 1980; Лопатин, 1992]. Образ Г. Потьомкіна став негативним антуражем, на тлі якого конструювався позитивний образ військового генія О. Суворова. Лише після лібералізації суспільногуманітарного життя в СРСР наприкінці XX ст. з'являються роботи, де переоцінена діяльність Г. Потьомкіна та зроблена спроба "переломити" ідеологічні конструкти імперської та радянської історіографії й вивести негативний образ Г. Потьомкіна з-за спини "позитивного" О. Суворова [Лопатин, 1992]. 
Очаківські події проходили у досить складній міжнародній ситуації. Проти реалізації "Грецького проекту" виступала Англія та Франція. У Російської імперії також складними були стосунки зі Швецією. Саме влітку Швеція під час осади Очакова, ключового форпосту Туреччини на Чорному морі, оголосила війну. Протистояння зі Швецією та відверта антиросійська "стримувальна" позиція Англії та Франції поховали надії на відкриття другого театру військових дій у Середземномор'ї, на що Росія сподівалась, фрормуючи середземноморську ескадру, яка, так само як і у війні 1768-1774 рр., мала відволікти сили османів із північнопричорноморського театру бойових дій. Така ситуація хоча й опосередковано, але пояснює нерішучість дій Г. Потьомкіна.

Г. Потьомкін не поспішав тому, що під час навігації був великий ризик вступу у війну Англії та пряма загроза Санкт-Петербургу. Англія прямо не втручалась у війну, але шукала слушного випадку. Таким випадком могло бути взяття Очакова, що спонукало б Англію негайно активно втрутитися в російсько-шведське протистояння, аби не допустити катастрофрічної поразки Османської імперії та закріплення Росії в північнопричорноморському регіоні. Аналіз листування Г. Потьомкіна та Катерини II говорить про те, що імператриця не дуже наполягала на негайному штурмі Очакова, на відміну від П. Румянцева та О. Суворова [Екатерина // и Потёмкин, 2010: 377-378]. Тому Г. Потьомкін дочекався часу, коли стане лід на Балтиці, і розпочав штурм, який завершив за одну добу.

Ці непопулярні, але необхідні дії Г. Потьомкіна в очаківській кампанії дуже сильно вплинули на його репутацію. Активізувалась антипотьомкінська група на чолі з П. Зубовим, куди примкнув і "аполітичний" О. Суворов. Саме тому владою і починають конструюватися та модернізуватися реальні сюжети у візуальних текстах очаківської тематики, де провідну роль відіграє Г. Потьомкін. У цих текстах він виступає в ролі благородного полководця, який вів у бій війська та здолав турків.

Однак після смерті Катерини II та в силу зміни владної кон'юнктури та ідеологічних установок, а також дещо негативного ставлення до Г. Потьомкіна серед деяких представників еліт починає формуватись інша іконологія в ідеологічних конструктах імперії. Унаслідок цього створений образ полководця-переможця Г. Потьомкіна переходить у тінь слави військового таланту О. Суворова. Саме навколо О. Суворова розпочинає формуватися новий "міф" непереможного полководця як один із головних елементів ідеологічного конструкту військової історії Російської імперії. Г. Потьомкін залишається в пантеоні лише як історичний діяч.

Свідченням цього факту є вихід у 1799-1801 рр. життєпису О. Суворова за авторством І. Антінга. Спеціально до цього видання С. Шубертом було створено серію гравюр [Антинट, 1800]. Автор сконструював сюжети навколо оборони Кінбурна, штурму Очакова та Ізмаїла, у центрі якого була персона О. Суворова, підкреслюючи саме його головну роль у цих ключових подіях. Реальний хід військових подій відображають умовно, але образ О. Суворова поданий детально. Згодом, через десять років, уже за Олександра I виходить робота "Жизнь генерала-фельдмаршала Потемкина Таврического", куди увійшли й гравюри з роботи С. Шуберта, де візуально виокремлюються заслуги О. Суворова в російсько-турецькому протистоянні та приєднання північнопричорноморського регіону [Траншан, Леже, 1811]. Характерною рисою цих видань $€$ те, що вміщені гравюри відповідають тексту та розміщені саме там, де йдеться про подію. Текст зосереджує увагу на елементах події, що зображена на гравюрі. Високий рівень зв'язку тексту та зображення й повторення цього прийому в різних виданнях свідчить, що візуальне було одним з елементів пропагандистської схеми, яка не фіксувала подію, а конструювала її з метою формування необхідної владі історичної пам'яті у своїх підданих.

\section{Висновки}

Таким чином, саме за часів Катерини II військові сюжети набувають поширення в живописі та графіці, поступаючись лише панівному напрямку - портретному жанру. Живопис та тиражна графіка починають активно використовуватись у конструюванні суспільної думки шляхом корегування образу. Аналіз творів живопису та гравюр, присвячених облозі Очакова 1788 р., говорить про деяку трансформацію історичної дійсності, яка була зафіксована М. Івановим, у роботах А. Барша та конструювання образу Г. Потьомкіна в роботах І. Вілля та Ф. Казанови. За допомогою цих засобів формування умовної реальності намагалися подолати "негативні наслідки" для іміджу Г. Потьомкіна, що виникли під час очаківської облоги.

\section{ЛПТРАТУРА}

1. Александр Васильевич Суворов: К 250-летию со дня рождения / отв. ред. Л. Г. Бескровный. Москва: Наука, 1980. $280 \mathrm{c}$.

2. Антинг И. Ф. Жизнь и военные деяния генералиссимуса, князя Италийского графра Суворова-Рымникского. СанктПетербург: Изд. Максима Парпуры, 1800. Ч. 2. 1800. 192 с.

3. Боннелл В. Крестьянка в политическом искусстве сталинской эпохи. Советская социальная политика 1920x - 1930-х годов: идеология и повседневность. Москва: Вариант, 2007. С. 262-294.

4. Брикнер А. Г. Потемкин. Санкт-Петербург: Издание К. Л. Риккера, 1891. 276 с.

5. Екатерина II и Потёмкин. Личная переписка (1769-1791). Москва: Директ-Медиа, 2010. С. 377-378.

6. Зорин А. Кормя двуглавого орла. Русская литература и государственная идеология в последней трети XVIII - первой трети XIX века. Москва: Новое литературное обозрение, 2001. $416 \mathrm{c}$.

7. Лопатин С. Потемкин и Суворов. Москва: Наука, 1992. $288 \mathrm{c}$.

8. Никольский Г. С. Суворовская "Наука побеждать". Москва: Министерство ВС СССР, 1949. 87 р.

9. Орлова Г. "Карты для слепых": политика и политизация зрения в сталинскую епоху. Визуальная антропология: режимы видимости при социализме. Москва: Вариант, 2009. C. $57-105$.

10. Осипов К. Суворов. Рига: Литгосиздат, 1949. URL: http:/ ladjudant.ru/suvorov/osipov08.htm (дата звернення: 12.06.2018)

11. Петров А. Н. Вторая турецкая война в царствование императрицы Екатерины II. 1787-1791 гг. Санкт Петербург: Тип. Р. Голике, 1880. Том I. 300 с.

12. Проскурина В. Мифы империи. Литература и власть в эпоху Екатерины II. Москва: Новое литературное обозрение, 2006. 328 c.

13. Траншан де Л., Леже М.-Ф. Жизнь генерал-фрельдмаршала князя Григория Александровича Потемкина Таврического. Санкт-Петербург: Тип. Ивана Глазунова, 1811. Т. 2. 140 с.

14. Цебриков Р. Вокруг Очакова. 1788 г. (Дневник очевидца). Русская Старина. 1895. Т. 84 (№ 9). С. 169.

15. Mitchell W. J. T. Showing seeing: a critique of visual culture. Journal of visual culture. 2002. Vol. 1. № 2. 258 p. 
Filas Viktor,

Candidate of Historical Sciences, Assistant Professor, Department of Design,

Khortytsia National Academy, Zaporizhzhia

\section{MANIPULATION BY VISUAL IMAGES IN IDEOLOGICAL CONCEPTS OR HOW THE G. POTIOMKIN'S IMAGE WAS "CLEANED UP"}

It is noted in the article that the graphic drawing from the end of the 18th century was actively used in forming public opinion through correction of images. With powerful levers, the state influenced on the subject of the work of art, formed the idea of the plot and the interpretation which it needed, introducing a certain set of ideas into the mass consciousness.

The peculiarities of producing and plotting works of painting and graphics covering the events of the RussianTurkish wars of the last quarter of the 18th century, speak about the policy of the establishment of G. Potemkin as a key figure in promoting the Russian Empire to the South during the implementation of the ideological concept of the Greek project.

On the basis of the analysis of works of painting and graphics devoted to the siege of Ochakov in 1788, the process of forming the image of G. Potemkin is observed against the background of his unpopular measures to take the fortress. After Ochakov's assault, custom-made oil paintings by F. Kazanov "Assault of Ochakov", A. Barsh's engravings and $\mathrm{I}$. Wille's engraving series devoted to the key themes of the process of taking the fortress, appeared. In addition, there are full-time eyewitnesses of the assault on the fortress of the artist M. Ivanov.

The conclusions indicate that it was during the days of Catherine II that military plots were spreading in graphic drawing, giving way only to the dominant direction - the portrait genre. The analysis of the works of painting and engravings devoted to the siege of Ochakov in 1788 suggests a certain transformation of historical reality, which was fixed by M. Ivanov in the works of A Barsh, and the construction of the positive image of G. Potemkin in the works of $I$. Wille and F. Kazanov. With the help of these means of formation of conditional reality, they tried to overcome the "negative consequences" for the reputation of G. Potemkin, which appeared during the Ochakov siege.

Key words: Northern Black Sea Region; Russian-Turkish wars; engraving; ideology; image; design.

\section{REFERENCE}

Beskrovny, G., 1980. Alexander Vasilievich Suvorov: To the 250th Anniversary of His Birth. Moscow: Nauka, 280 p. (rus).

Anting, I., 1800. Life and Military Actions of the Generalissimo, Prince of the Italian Earl Suvorov-Rymninskiy. St. Petersburg: Maxim Parpur publishing house, Ch. 2. 192 p. (rus).

Bonnell, V., 2007. Peasant Woman in the Political Art of the Stalin Era. Soviet Social Policy of the 1920s-1930s: Ideology and Everyday Life. Moscow: Variant: 262-294 (rus)

Brikner, A., 1891. Potemkin. St. Petersburg: The edition of K. L. Rikker, 276 p.

Catherine II and Potemkin. 2010. Personal Correspondence (1769-1791). Moscow: Direct-Media, 377-378.

Zorin, A., 2001. Feeding the Double-Headed Eagle. Russian Literature and State Ideology in the last third of the XVIII - first third of the XIX century. Moscow: New Literary Review, 416 p.

Lopatin, S., 1992. Potemkin and Suvorov. Moscow: Science, 288 p.

Nikolsky, G., 1949. Suvorov's "Science of winning". Moscow: Ministry of the Armed Forces of the USSR, $87 \mathrm{p}$

Orlova, G., 2009. "Maps for the Blind": Politics and Politicization of View in the Stalin Era. Visual anthropology: Modes of Visibility Under Socialism. Moscow: Variant, P. 57-105.

Osipov, K., 1949. Suvorov. Riga: Litgosizdat, URL: http://adjudant.ru/suvorov/osipov08.htm

Petrov, A. 1880. The Second Turkish War in the Reign of Empress Catherine II. 1787-1791 St. Petersburg: Type. R. Golike, Volume I. $300 \mathrm{p}$.

Proskurina, V., 2006. Myths of the Empire. Literature and Power in the Era of Catherine II. Moscow: New Literary Review, $328 \mathrm{p}$

Tranchan, de L., Leger, M.-F. 1811. Life of General-Field Marshal Prince Grigory Alexandrovich Potemkin Tavrichesky. T. 2. St. Petersburg: Type. Ivan Glazunov, $140 \mathrm{p}$.

Tsebrikov, R. 1895. Around Ochakov, 1788 (Diary of an Eyewitness). Russian Antiquity. 84 (No. 9). P. 169.

Mitchell, W., 2002. Showing Seeing: a Critique of Visual Culture. Journal of Visual Culture. Vol. 1. № 2. 258 p.

() Філас Віктор

Надійшла до редакції 13.08.2018 